\title{
MODEL PENGEMBANGAN DESA WISATA BERBASIS KOMODITAS LOKAL DI KABUPATEN BANTUL DAERAH ISTIMEWA YOGYAKARTA
}

\author{
Hastuti dan Nurul Khotimah \\ Fakultas Ilmu Sosial Universitas Negeri Yogyakarta \\ email: hastuti@uny.ac.id
}

\begin{abstract}
Abstrak: Model Pengembangan Desa Wisata Berbasis Komoditas Lokal di Kabupaten Bantul Daerah Istimewa Yogyakarta. Tujuan dari penelitian ini adalah: (1) mengetahui potensi desa wisata berbasis komoditas lokal, dan (2) menemukan dan mengembangkan model pengembangan Desa Wisata berbasis komoditas lokal di Kabupaten Bantul. Penelitian ini menggunakan desain penelitian dan pengembangan (Research and Development). Sampel penelitian dipilih secara purposif yakni Desa Wisata Krebet. Jenis data penelitian meliputi data primer dan data sekunder. Data dikumpulkan dengan menggunakan studi literatur, observasi, wawancara, dan Focus Group Discussion . Data dianalisis dengan menggunakan teknik analisis deskriptif. Hasil penelitian ini menunjukkan bahwa pertama, potensi Desa Wisata Krebet adalah sentra kerajin-an batik kayu, dengan (1) produk kerajinan yang dihasilkan adalah topeng, wayang, almari, aksesoris rumah tangga, patung kayu, kotak perhiasan, dan hiasan batik kayu lainnya, (2) motif batik kayu yang dibuat adalah motif parangrusak, parangbarong, kawung, garuda, sidorahayu, sidomukti, dan motif lainnya. Kedua, Desa Wisata Krebet dijadikan model pengembangan desa wisata berbasis komoditas lokal berupa sentra kerajinan batik kayu, dengan pertimbangan adanya kegiatan ekonomi produktif, adanya kegiatan sosial budaya yang dilestarikan penduduk setempat, adanya pengembangan jelajah wisata hutan rakyat atau perkebunan, dan adanya potensi desa wisata.
\end{abstract}

Kata kunci: model, pengembangan, desa wisata, komoditas lokal

\begin{abstract}
Local Commodities based Tourism Village Development Model in Bantul, Yogyakarta. This study was aimed at (1) determining the potency of local commodity-based tourism village, and (2) finding out and developing tourism village development model based on local commodity in Bantul. This study used research and Research and Development method. The sample of the research was chosen purposively ie Krebet Tourism Village. The types of research data include primary data and secondary data. The data were collected using literature study, observation, interview, and Focus Group Discussion. The data were analyzed using descriptive analysis technique. The results show that first, Krebet Tourism Village potential is a center of wooden batik handicraft, with (1) various handicraft products: mask, wayang, wardrobe, household accessories, wooden sculpture, jewelry box, and other wooden batik decoration , (2) various batik motif: parangrusak, parangbarong, kawung, garuda, sidorahayu, sidomukti, and other motifs. Secondly, Krebet Tourism Village is used as a model of local commodities-based tourism village in the form
\end{abstract}


of wooden batik center because of some considerations, namely the existence of productive economic activities, the existence of socio-cultural activities that are preserved by local residents, the development of cruise tourism or public forest plantations, the potential of tourist villages.

Keywords: local commodities, tourism village, wooden batik

\section{PENDAHULUAN}

Desa wisata merupakan bentuk integrasi antara atraksi, akomodasi, dan fasilitas yang disajikan dalam suatu struktur kehidupan masyarakat yang menyatu dengan tradisi setempat (Ditjen Pengembangan Destinasi, 2009). Desa wisata merupakan salah satu pendekatan pengembangan wisata alternatif. Pengembangan desa wisata sebagai pusat kegiatan ekonomi, sosial, dan budaya, salah satunya dapat dilakukan dengan pemanfaatan sumberdaya berbasis komoditas lokal, dalam penelitian ini difokuskan pada keberadaan sentra industri. Pengembangan desa wisata berbasis komoditas lokal diharapkan dapat melahirkan berbagai kegiatan produksi sebagai alternatif sumber pendapatan yang memadai bagi masyarakat perdesaan tanpa harus meninggalkan mata pencaharian utama di sektor pertanian. Strategi pengembangan pariwisata diperlukan demi terwujudnya kesejahteraan masyarakat (Carlsen \& Butler, 2011).

Kabupaten Bantul merupakan salah satu wilayah di Daerah Istimewa Yogyakarta yang memiliki desa wisata cukup banyak dan berbasis komoditas lokal (sentra industri). Ragam industri sebagai komoditas lokal di Kabupaten Bantul cukup banyak, mulai dari industri kerajinan berbasis kayu, kertas, logam, tanah, limbah, kulit sampai garmen. Industri yang beraneka ragam tersebut pada umumnya terkumpul dalam sentra-sentra industri. Dalam Rencana Pembangunan Jangka Menengah Daerah (RPJMD) Kabupaten Bantul Tahun 20112015 disebutkan bahwa tada tahun 2009 di Kabupaten Bantul telah terbentuk 73 sentra industri. Di antara industri yang beraneka ragam tersebut, pemerintah Kabupaten Bantul telah menetapkan beberapa macam industri sebagai komoditas terpilih yang diklasifikasikan dalam komoditas unggulan, komoditas andalan, dan komoditas yang diunggulkan.

Munculnya desa wisata di Kabupaten Bantul berbasis komoditas lokal (sentra industri) maka akan menambah objek dan daya tarik wisata di Kabupaten Bantul, yang selanjutnya dapat mendukung peningkatan pendapatan daerah, bahkan meningkatkan kesejahteraan masyarakat di sekitarnya. Potensi ini tentunya memerlukan perhatian serius, mengingat potensi di suatu wilayah akan bermanfaat apabila dapat dikelola oleh penduduk setempat. Konsep dasar pemanfaatan potensi wilayah sebagai langkah untuk meningkatkan kesejahteraan penduduk di perdesaan (Baiquni, 2006), yaitu: (1) memerlukan peran serta aktor lokal untuk memanfaatkan sumberdaya perdesaan secara berkelanjutan, (2) meningkatkan produktivitas melalui perbaikan regenerasi sumber daya perdesaan, (3) meningkatkan kesejahteraan yang berkeadilan, (4) meningkatkan kualitas hidup dan pengetahuan lokal, dan (5) memperhatikan kemampuan daya dukung sumberdaya perdesaan yang 
berkelanjutan.

Sastrayuda (2010) menyebutkan bahwa unsur penting pengembangan desa wisata berkelanjutan adalah pelatihan masyarakat dari berbagai tingkat pendidikan, mengingat pengelolaan desa wisata memerlukan sumber daya manusia berkualitas dan profesional. Unsur penting lainnya adalah pembentukan kelompok pengusaha lokal dan pembinaannya sehingga mampu memunculkan produk lokal seperti barang kerajinan, makanan/ minuman khas, dan produk lainnya yang dapat mempromosikan kekhasan desa wisata.

Beberapa permasalahan yang dijumpai di lapangan terkait upaya pengembangan desa wisata berbasis komoditas lokal (sentra industri) adalah: (1) nilai tambah produk yang relatif kecil dikarenakan modal kecil sehingga kesempatan berekspansi menjadi terbatas, (2) kualitas sumberdaya manusia relatif rendah sehingga tingkat kreativitas dan inovasi produksi juga rendah, (3) jaringan pemasaran yang dimiliki terbatas, dan (4) sistem manajemen organisasi belum berjalan dengan baik. Berbagai permasalahan tersebut memerlukan penanganan lebih lanjut, jika tidak ingin tertinggal dan tersingkir dari perkembangan ekonomi di era pasar bebas.

Wilayah perdesaan di Kabupaten Bantul memiliki potensi (kekuatan dan kelemahan) yang dapat dijadikan dasar bagi masyarakat setempat untuk menangkap peluang dan melakukan tindakan terkait kegiatan desa wisata berbasis komoditas lokal guna peningkatan pendapatan rumah tangga dan peningkatan kesejahteraan masyarakat. Dukungan secara berkelanjutan terhadap potensi wilayah oleh berbagai pihak menjadi modal penting dalam pengembangan desa wisata berbasis komoditas lokal. Dukungan terhadap potensi wilayah tidak hanya dari pemerintah dan lembaga swadaya masyarakat, tetapi juga memerlukan partisipasi masyarakat secara aktif untuk mengelola potensi tersebut.

Berdasarkan permasalahan yang diuraikan di atas, maka diperlukan penelitian secara mendalam tentang pengembangan desa wisata berbasis komoditas lokal di Kabupaten Bantul. Tujuan yang ingin dicapai dalam penelitian ini adalah: (1) mengetahui potensi pengembangan desa wisata berbasis komoditas lokal, (2) menemukan dan mengembangkan model pengembangan desa wisata berbasis komoditas lokal. Pengembangan desa wisata berbasis komoditas lokal diharapkan mampu menjadi stimulus untuk peningkatan kegiatan ekonomi, sosial, dan perbaikan lingkungan guna mewujudkan kesejahteraan masyarakat yang berkelanjutan.

\section{METODE}

Penelitian ini menggunakan desain penelitian dan pengembangan (Research and Development). Luaran yang diharapkan dari penelitian ini adalah: (1) analisis dan pembaruan informasi potensi desa wisata berbasis komoditas lokal, (2) model pengembangan desa wisata berbasis komoditas lokal di Kabupaten Bantul. Produk hasil penelitian disajikan dalam bentuk sistem informasi desa wisata berbasis komoditas lokal dalam bentuk cetak.

Lokasi penelitian adalah desa wisata di Kabupaten Bantul yang memiliki potensi untuk dikembangkan kegiatan desa wisata berbasis komoditas lokal. Pemilihan sampel wilayah penelitian di Kabupaten Bantul dilakukan secara purposive. Adapun yang menjadi pertimbangan penentuan wilayah penelitian adalah pendekatan geografi, yaitu pendekatan keruangan sehingga diharapkan dapat mengungkap 
tentang pengembangan desa wisata berbasis komoditas lokal di Kabupaten Bantul. Wilayah penelitian berada di 3 (tiga) lokasi, meliputi Desa Wisata Wukirsari, Desa Wisata Krebet, dan Desa Wisata Kasongan. Dalam artikel ini akan lebih difokuskan pada kajian Desa Wisata Krebet.

Data yang dikumpulkan untuk mendukung penelitian ini adalah data primer dan data sekunder. Teknik pengumpulan data meliputi studi pustaka, observasi, wawancara, dan Focus Group Discussion (FGD). Studi pustaka dilakukan melalui referensi buku, majalah, jurnal, internet maupun hasil penelitian sebelumnya. Observasi dilakukan melalui penjajagan dan pengamatan di wilayah penelitian. Wawancara dilakukan menggunakan instrumen penelitian. FGD dilakukan untuk menentukan dan memperkirakan peluang usaha komoditas lokal yang telah ada dan telah dikembangkan menjadi sentra industri komoditas lokal, untuk selanjutnya dijadikan sebagai komoditas unggulan dan menjadi nilai tawar dalam menentukan model pengembangan desa wisata berbasis komoditas lokal. Analisis data penelitian dilakukan secara deskriptif. Analisis deskriptif dilakukan untuk lebih menjelaskan hal-hal terkait dengan fenomena penelitian.

\section{HASIL DAN PEMBAHASAN Potensi Desa Wisata Krebet Berbasis Komoditas Lokal}

Desa Wisata Krebet terletak di Dusun Krebet, Desa Sendangsari, Kecamatan Pajangan, Kabupaten Bantul, kurang lebih $12 \mathrm{~km}$ barat daya Kota Yogyakarta. Perjalanan menuju Krebet dapat ditempuh menggunakan bus, mobil pribadi, maupun sepeda motor. Krebet terletak di wilayah perbukitan dengan tanah grumusol dan litosol yang berasal dari batuan induk batugamping. Dulu masyarakat Krebet mengandalkan pertanian sebagai sumber mata pencaharian, tetapi karena kegiatan pertanian bersifat tadah hujan, maka kemudian mengembangkan keahlian lain untuk membuat barang-barang kerajinan dari kayu yang dibatik, sehingga Krebet dikenal menjadi sentra kerajinan batik kayu.

Krebet dihuni sejumlah 905 jiwa penduduk, dengan tingkat pendidikan sebagian besar tamat SMP dan SMA. Mata pencaharian penduduk Krebet sebagian besar adalah sebagai pengrajin. Berbagai produk kerajinan yang dihasilkan adalah topeng, wayang, almari, aksesoris rumah tangga, patung kayu, kotak perhiasan, dan hiasan batik kayu lainnya dengan kisaran harga mulai dari yang murah hingga jutaan rupiah. Proses pembatikan dengan menggunakan media kayu sama dengan pada media kain, yaitu menggunakan canting. Dalam proses membatik, para pengrajin membuat pola secara manual sehingga dalam membatik membutuhkan tingkat ketelitian tinggi. Motif batik kayu yang dibuat adalah motif parangrusak, parangbarong, kawung, garuda, sidorahayu, sidomukti, dan motif lainnya. Produk kerajinan tersebut tidak hanya dipasarkan di dalam negeri, tetapi juga telah dipasarkan ke mancanegara (Hastuti \& Khotimah, 2016).

Desa wisata Krebet telah memiliki sekretariat. Struktur organisasi Desa Wisata Krebet meliputi Pembina (Dinas Kebudayaan dan Pariwisata Kabupaten Bantul), penasehat (Forum Komunikasi Kelompok Sadar Wisata Kabupaten Bantul), Ketua, Wakil Ketua, Sekretaris, Bendahara, Seksi Keamanan, Seksi Keindahan, Seksi Kebersihan, Seksi Keramahan, Seksi Kenangan, dan Pembantu Umum. Untuk mendukung keberadaaan Desa Wisata Krebet, penduduk setempat juga menawarkan fasilitas homestay bagi wisatawan yang 
ingin mengenal lebih jauh tentang proses pembuatan kerajinan batik kayu atau menikmati suasana alam pedesaan Krebet yang masih asri atau untuk belajar bertani kepada penduduk setempat. Selain mengembangkan potensi alam, penduduk Krebet juga mengembangkan potensi sosial budaya. Penduduk Krebet rutin menyelenggarakan upacara Merti Dusun sebagai ungkapan rasa syukur kepada Tuhan Yang Maha Esa atas hasil bumi yang melimpah (Hastuti \& Khotimah, 2016). Upacara Merti Dusun berlangsung dengan pengarakan gunungan yang berisi bahan makanan pokok menyusuri jalan Dusun Krebet oleh prajurit diikuti oleh penduduk lainnya yang membawa ubo rampe kenduri. Setelah gunungan diarak sampai pendapa, gunungan diserahkan kepada sesepuh untuk diadakan doa bersama kemudian gunungan dan ubo rampe dibagikan pada penduduk dengan cara rebutan untuk mengambil makanan yang berupa gunungan tersebut.

Gunn (Rindrasih, 2015) menyatakan bahwa untuk perencanaan pariwisata ada tiga hal sebagai dasar. Pertama, seluruh daerah dan negara harus mengembangkan perencanaan pariwisata sesuai dengan frameworks mereka dalam politik dan ideologi. Kedua, perencanaan pariwisata harus mempertimbangkan ungsi saling mempengaruhi antara supply dan demand dalam sebuah sistem pariwisata. Ketiga, fungsi dasar dari sistem dipengaruhi oleh faktor eksternal berupa kualitas sumberdaya alam dan budaya, pengusaha, modal, pekerja, kompetisi, kondisi sosial ekonomi, sikap masyarakat, kebijakan pemerintah, dan organisasi yang dapat mempengaruhi supply dan kepuasan pasar.

Hal pertama yang menjadi keunggulan Desa Wisata Krebet adalah daerah yang perencanaan pariwisatanya dikembangkan sesuai framework yaitu berkaitan desa wisata lain dengan komoditas sektoral/komoditas lokal yang berbeda, misalnya Desa Wisata Kasongan dengan komoditas lokal berupa gerabah/ keramik dan Desa Wisata Wukirsari dengan komoditas lokal berupa wayang kulit dan batik tulis. Hal kedua adalah terjadinya koneksitas terhadap desa di sekitarnya. Dalam hal ini sebagai sebuah framework untuk saling mencukupi atau memenuhi berbagai hal untuk mendukung pengembangan pariwisata terutama memenuhi tenaga kerja dan bahan baku khususnya kayu yang bisa diperoleh di sekitar Desa Wisata Krebet. Hal ketiga adalah adanya peran aktif masyarakat untuk menggunakan media sosial sebagai alat utama pemasaran dan sekaligus promosi keberadaan Desa Wisata Krebet sehingga mampu mendatangkan pemodal dan pembeli. Hal ini juga tidak lepas dari peran Pemerintah Kabupaten Bantul yang gencar mengembangkan desa wisata berbasis komoditas lokal.

Desa Wisata Krebet dengan komoditas lokal berupa batik kayu termasuk komoditas andalan di Kabupaten Bantul. Kerajinan kayu, seperti batik kayu di Desa Wisata Krebet termasuk komoditas andalan karena pemakaian bahan baku lokal 60-69\%, mampu menyerap tenaga kerja (padat karya), mempunyai nilai ekspor > US\$ 0,5-1 juta, tujuan ekspor minimal dua negara, dan pertumbuhan ekspor 5-10\% selama lima tahun terakhir. Mode dan desain yang semakin bagus dan menarik yang dapat dapat diikuti oleh pengrajin kayu di Desa Wisata Krebet diharapkan dapat menjadikan komoditas lokal berupa batik kayu dapat masuk dalam kelompok industri unggulan di Kabupaten Bantul, seperti industri gerabah/keramik di Desa Wisata Kasongan. 
Model Pengembangan Desa Wisata Krebet Berbasis Komoditas Lokal

Desa wisata sebagai salah satu pendekatan pengembangan wisata alternatif, maka dalam pemodelan desa wisata dapat dilakukan dengan mengembangkan komoditas lokal berupa sentra kerajinan batik kayu (Hastuti \& Khotimah, 2016). Komoditas lokal berupa sentra kerajinan batik kayu dapat dipengaruhi oleh kegiatan ekonomi produktif, kegiatan sosial budaya, kegiatan pertanian/perkebunan, dan potensi desa wisata. Aspek penting lainnya dalam upaya pengembangan desa wisata adalah partisipasi penduduk setempat untuk penyediaan sarana prasarana pendukung (Hastuti \& Khotimah, 2016).

Desa Wisata Krebet dijadikan model pengembangan desa wisata berbasis komoditas lokal berupa sentra kerajinan batik kayu, dengan beberapa pertimbangan. Pertama, adanya kegiatan ekonomi produktif yang diupayakan penduduk setempat berupa catering, warung makan, oleh-oleh khas gula jawa Krebet, dan sablon kaos Desa Wisata Krebet. Kedua, adanya kegiatan sosial budaya yang dilestarikan penduduk setempat berupa merti dusun, kethoprak, jathilan, dan keterdapatan organisasi pengelola desa wisata. Ketiga, adanya pengembangan jelajah wisata hutan rakyat atau perkebunan. Keempat, adanya potensi desa wisata berupa keterdapatan tempat wisata air terjun "Jurang Pulosari", ketersediaan air mencukupi, aksesibilitas memadai, pemandangan alam yang indah, terjangkau wifi, adanya kursus belajar membatik pada media kayu, dan adanya paket wisata yang dikelola sekretariat (Hastuti \& Khotimah, 2016).

Model pengembangan Desa Wisata Krebet berbasis komoditas lokal dapat dilihat pada Gambar 1.

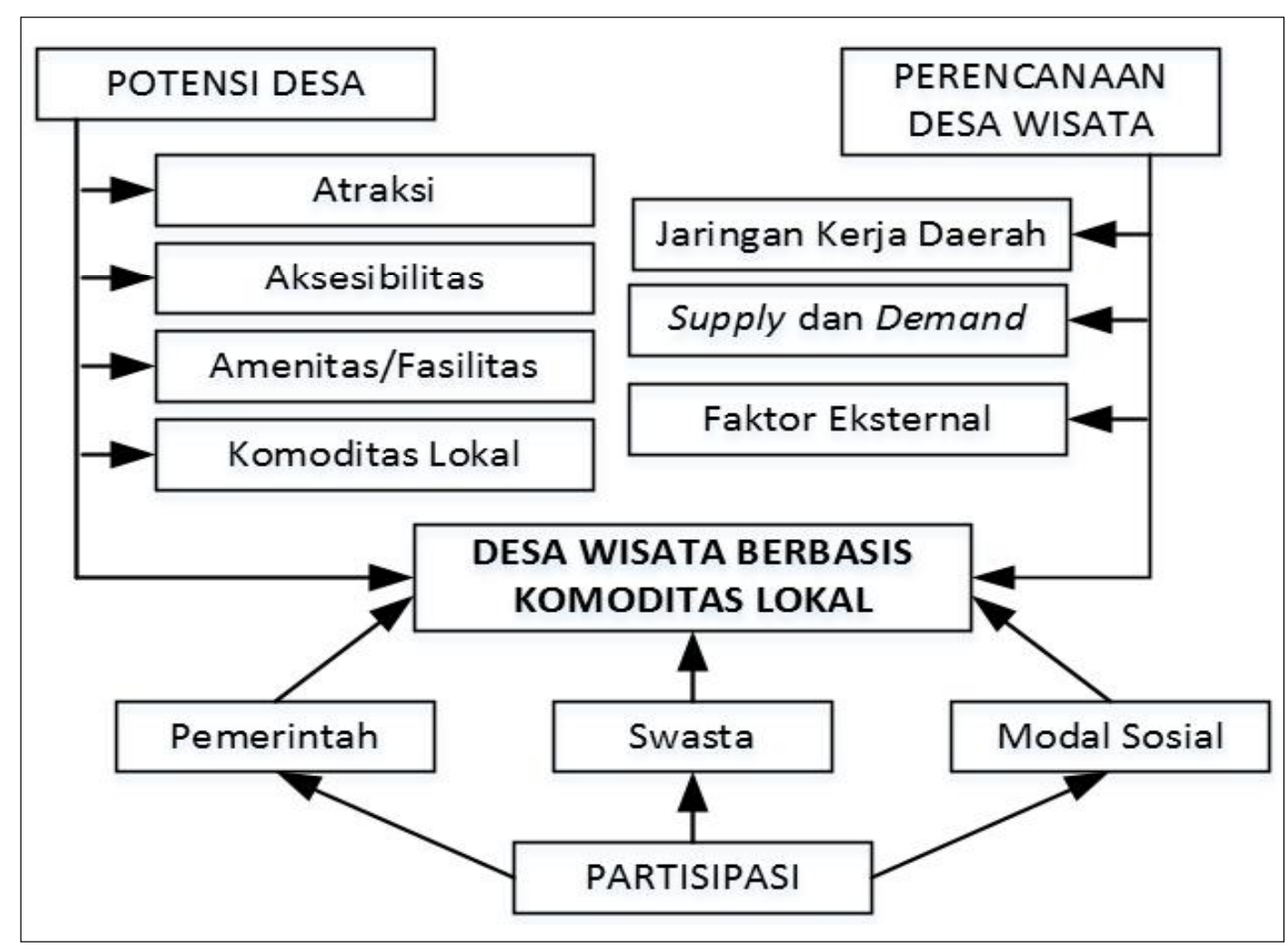

Gambar 1. Model Pengembangan Desa Wisata Krebet Berbasis Komoditas Lokal 


\section{SIMPULAN}

Dari uraian pada hasil penelitian dan pembahasan dapat disimpulkan sebagai berikut. Pertama, potensi Desa Wisata Krebet adalah sentra kerajinan batik kayu, dengan: (a) produk kerajinan yang dihasilkan adalah topeng, wayang, almari, aksesoris rumah tangga, patung kayu, kotak perhiasan, dan hiasan batik kayu lainnya, (b) motif batik kayu yang dibuat adalah motif parangrusak, parangbarong, kawung, garuda, sidorahayu, sidomukti, dan motif lainnya. Kedua, Desa Wisata Krebet dijadikan model pengembangan desa wisata berbasis komoditas lokal berupa sentra kerajinan batik kayu, dengan pertimbangan: (a) adanya kegiatan ekonomi produktif yang diupayakan penduduk setempat berupa catering, warung makan, oleh-oleh khas gula jawa Krebet, dan sablon kaos Desa Wisata Krebet, (b) adanya kegiatan sosial budaya yang dilestarikan penduduk setempat berupa merti dusun, kethoprak, jathilan, dan keterdapatan organisasi pengelola desa wisata, (c) adanya pengembangan jelajah wisata hutan rakyat atau perkebunan, (d) adanya potensi desa wisata berupa keterdapatan tempat wisata air terjun "Jurang Pulosari", ketersediaan air mencukupi, aksesibilitas memadai, pemandangan alam yang indah, terjangkau wifi, adanya kursus belajar membatik pada media kayu, dan adanya paket wisata yang dikelola sekretariat.

Rekomendasi yang diberikan untuk pengembangan Desa Wisata Krebet sebagai desa wisata berbasis komoditas lokal sebagai berikut. Pertama, bagi Pemerintah, khususnya Dinas Kebudayaan dan Pariwisata Kabupaten Bantul hendaknya terus mendorong secara konkret upaya-upaya pembangunan desa wisata di wilayahnya. Kedua, bagi masyarakat, diharapkan untuk terus menjaga kualitas komoditas lokal dan kelestarian lingkungan di sekitar desa wisata dalam menunjang keberlanjutan pengembangan Desa Wisata Krebet.

\section{DAFTAR PUSTAKA}

Baiquni. 2006. "Pengelolaan Sumberdaya Perdesaan dan Strategi Penghidupan Rumahtangga di DIY Masa Krisis (19982003)". Disertasi. UGM, Yogyakarta.

Carlsen, J., \& Butler, R. 2011. Island Tourism Sustainable Perspectives. Wallingford: CABI CAB International.

Rindrasih, E. 2015. Menilik Pengembangan Desa Wisata di Taman Nasional. Membangun Pariwisata dari Bawah: Catatan Penelitian terhadap Desa Wisata Penerima PNPM Mandiri Pariwisata. Yogyakarta: Gadjah Mada University Press.

Sastrayuda, G. S. 2010. Handout Mata Kuliah Concept Resort and Leisure, Strategi Pengembangan dan Pengelolaan Resort and Leisure (Tidak diterbitkan). Bandung.

Hastuti, \& Khotimah, N. 2016. "Model Pengembangan Desa Wisata Berbasis Komoditas Lokal di Kabupaten Bantul Daerah Istimewa Yogyakarta". Laporan Penelitian Hibah Bersaing. Universitas Negeri Yogyakarta, Yogyakarta.

Rencana Pembangunan Jangka Menengah Daerah (RPJMD) Kabupaten Bantul Tahun 2011-2015. Diunduh dari http://bappeda.bantulkab.go.id/ d a ta / hal / 0 / 0 / 7 / 23 - r p j m d kabupaten-bantul-2011-2015 tanggal 15 Juli 2014.

Ditjen Pengembangan Destinasi. 2009. Pengembangan Desa Wisata sebagai Daya Tarik Wisata Berbasis Komunitas. Laporan tidak diterbitkan. Jakarta: Departemen Kebudayaan dan Pariwisata, Ditjen Pengembangan Destinasi. 